Designer Eggs with an Increased Content of Omega-3 fatty Acids and Pigments - Production and Health Benefits of their Consumption

Dizajnirana jaja s povećanim sadržajem omega-3 masnih kiselina i pigmenata - proizvodnja i zdravstvena korist njihove konzumacije

Kralik, Z., Kralik, G., Grčević, M., Hanžek, D., Biazik, E.

Poljoprivreda/Agriculture

ISSN: $1848-8080$ (Online)

ISSN: 1330-7142 (Print)

https://doi.org/10.18047/poljo.27.2.9

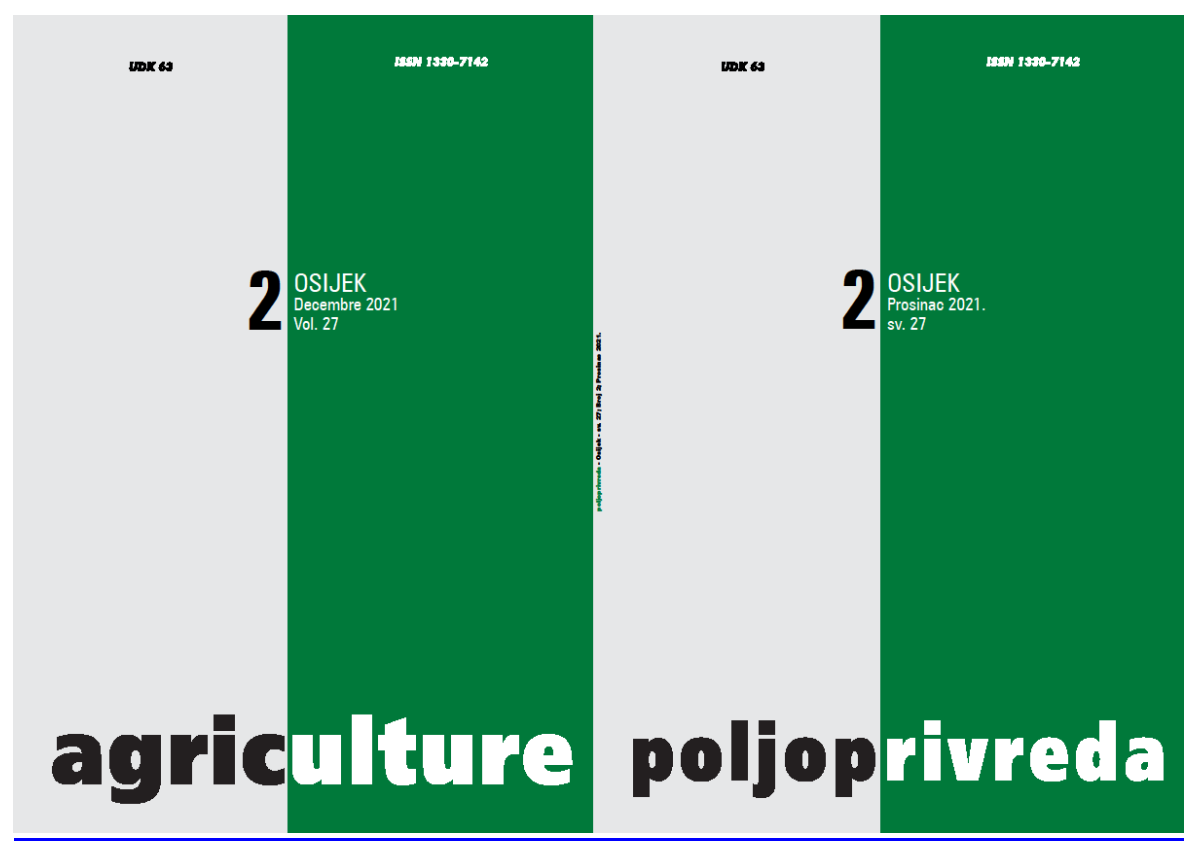

Fakultet agrobiotehničkih znanosti Osijek, Poljoprivredni institut Osijek

Faculty of Agrobiotechnical Sciences Osijek, Agricultural Institute Osijek 
ISSN $1330-7142$

$U D K=637.482: 614$

https://doi.org/10.18047/poljo.27.2.9

\title{
DESIGNER EGGS WITH AN INCREASED CONTENT OF OMEGA-3 FATTY ACIDS AND PIGMENTS - PRODUCTION AND HEALTH BENEFITS OF THEIR CONSUMPTION
}

Kralik, Z. ${ }^{(1,2)}$, Kralik, G. ${ }^{(2,3)}$, Grčević, M. ${ }^{(1,2)}$, Hanžek, D. ${ }^{(1,2)}$, Biazik, E. ${ }^{(4)}$

\author{
Scientific review \\ Pregledni znanstveni članak
}

\begin{abstract}
SUMMARY
Designed-enriched products have been recently one of the most interesting areas of research and innovation in the animal production and food industry. These products are considered functional foods and contain ingredients that have beneficial physiological effects on human health. Designed or enriched eggs are an important type of functional food in poultry production. Demand for functional foods in the market has been increasing in recent years. Due to the increased interest of people in buying designed products, there is a production adjustment in the poultry industry. Composition change of laying hens feed affects nutritional composition change of eggs as well as their quality preservation. This process can an effect of the change in the concentration of cholesterol and its fractions, fatty acids, and pigments in eggs. It is evident from the relevant scientific literature that designer eggs consumption can have a positive effect on human health. Therefore, the aim of this paper is to describe different concepts of designer eggs production and emphasize the health benefits of their consumption in humans.
\end{abstract}

Keywords: designer eggs, functional foods, omega-3 fatty acids, pigments

\section{INTRODUCTION}

Egg is an important source of quality proteins, fats, vitamins, and microelements for consumers. Li et al. (2013) pointed out that eggs' composition, for a while, caused controversial opinions among nutritionists and health agencies due to the content of saturated fats and cholesterol ( $3 \mathrm{~g}$ and $200-300 \mathrm{mg} / 100 \mathrm{~g}$, respectively). Due to the above mentioned they recommended people to consume as little eggs as possible. Increased egg consumption due to cholesterol intake was thought to be the cause of cardiovascular disease in humans. However, various studies confirm that eggs cholesterol has a limited effect on blood cholesterol levels leading to cardiovascular diseases occurrence in humans (Djoussé, and Gaziano, 2008; Eilat-Adar et al., 2013;
Stupin et al., 2018). Flaxseed oil and seeds use, as well as fish oil, in laying hens feed increased the omega-3 fatty acids content in the yolks and at the same time reduced the cholesterol content (Basmacıoğlu et al., 2003; Mattioli et al., 2016). These authors assume that the cholesterol content change in yolks is in correlation with the omega-3 fatty acids ( $n-3$ PUFA) concentration.

(1) Assoc. Prof. Zlata Kralik (zlata.kralik@fazos.hr), Manuela Grčević, Ph.D., Danica Hanžek, Mag. Eng. Agr. - Josip Juraj Strossmayer University of Osijek, Faculty of Agrobiotechnical Sciences Osijek, Vladimira Preloga 1, 31000 Osijek, Croatia, (2) Josip Juraj Strossmayer University of Osijek, Scientific Center of Excellence for Personalized Health Care, Trg Svetog Trojstva 3, 31000 Osijek, Croatia, (3) Prof. Emer. Dr. Dr. h. c. Gordana Kralik - Nutricin j. d. o. o. Darda, Braće Radića 6, 31326 Darda, Croatia, (4) Ewa Biazik, Ph.D. - Department of Agroengineering and Quality Analysis, Faculty of Engineering and Economics, Wroclaw University of Economics and Business, Komandorska 180/120 Street, 53-345 Wroclaw, Poland 
By feeding the laying hens specially designed feed, it is possible, apart from fatty acids composition change in eggs, to change some pigments content. Laying hens feed supplemented with pigments increase their egg content and affects the yolk color change. Carotenoids, lutein, and zeaxanthin are most often added to feed (Grčević et al., 2019; Kralik et al., 2018; Kralik et al., 2020a).

The eggs production with increased lutein content is important since it has been proved that the consumption of these eggs has a prevention effect on the macular degeneration occurrence in humans (AlvesRodrigues and Shao, 2004). Designer eggs are available on the world market under different names defined by the ingredient increased according to the geographical area, the population they are intended for or the chicken's keeping system. Omega-3, Columbus eggs, Omega DHA eggs, Suguna vitamin D eggs, Eggs Plus, Selenium Plus, Dr. Selenium, Vi omega-3, NutriPlus, Bounty Eggs, Mr Eggs and the like are known on the world market (Lyons et al., 2007; Kralik et al., 2016). In Europe, the role of nutrition in health care has become increasingly pronounced for more than 10 years (Biacs, 2007). Europeans are generally far more critical towards new products and technologies in food production compared to American consumers (Bech-Larsen and Grunert, 2003; Lusk et al., 2004; Lusk and Rozan, 2005). By the literature it can be concluded that the main reasons for buying new innovative functional products are health care, better product quality, brand recognition and practical packaging. However, the reasons for not buying such products are mainly insufficient product information, too high price and poor market availability. In general, the younger population, who have higher monthly incomes, are more likely to buy functional products unlike those with lower monthly incomes while older population is more likely to buy these products due to their positive health effect (Labrecque et al., 2006; Williams et al., 2008; Kralik et al., 2016). Innovative functional products, such as designer eggs, are the result of modern development trends in egg production, and are in high demand in the domestic market, but are also highly valued export goods (Lesnierowski and Stangierski 2018).

\section{EGGS WITH A MODIFIED FATTY ACID PROFILE}

Eggs are a good source of essential nutrients. Interest in the impact of fatty acids (FA) on human health (Candela et al., 2011) has been recently increasing. "Designer" eggs (Surai and Sparks, 2001) contain, apart from nutrients, ingredients having a beneficial effect on physiological processes and human health unlike those from the conventional composition (Bubel et al., 2011). Especially significant are $n-3$ polyunsaturated fatty acids ( $n-3$ PUFA): long-chain - LC PUFA (Fraeye et al., 2012), a-linolenic (ALA), eicosapentaenoic (EPA) and docosahexaenoic (DHA). This is the reason why compositions of laying hens feed are modified in terms of type, amount and fats composition aiming to induce metabolic changes affecting the synthesis and deposition of desirable fatty acids (Sahoo and Jena, 2014). Yolk's fat content is mostly constant, but the fatty acid profile is variable being used in practice (Zaheer, 2015). Conventional eggs contain high concentrations of $n-6$ PUFA and are poor in n-3 PUFA. The content increase of ALA, EPA and DHA in the yolk changes the n-6 PUFA/n-3 PUFA ratio being very unfavorable in some cases. According to the USDA, this ratio is 19.4 (Simopoulos, 2000). Stibilj et al. (1999) cited 13.44, Kralik et al. (2020.b) 4.23 to 10.65 , and Lešić et al. (2015) even 36.7, 43.3 and 62.3. Eggs can be supplemented with ALA, a precursor of long-chain fatty acids EPA and DHA, but synthesis is limited in the human body (Aydin and Dogan, 2010). Vegetable oils such as flaxseed, soybean and rapeseed are used for this purpose (Petrović et al., 2012; Muduli et al., 2018). The best sources of $n-3$ PUFAs are fish oil (Coorey et al., 2015), microalgae, or their combination (Baucells et al., 2000; Kralik et al., 2020b; Kralik Z. et al., 2020). These additives are used in certain concentrations in the laying hens feed aiming not to disturb the eggs organoleptic properties. Ways of enriching table eggs with ALA, EPA and DHA using vegetable oils, fish oil and marine microalgae oil are shown in Table 1.

The efficiency analysis of egg yolks enrichment with fatty acids, according to the presented authors, shows that ALA can be increased up to 11.6 times, EPA 36.0 times, DHA 4.04 times, and $\sum$ n-3 PUFA up to 6.64 times compared to the control group and depending on the source and the concentration of fatty acids in the feed fed to the laying hens. 
Table 1. Enrichment of table eggs with n-3 PUFA

Tablica 1. Obogaćivanje konzumnih jaja s n-3 PUFA

\begin{tabular}{|c|c|c|c|c|c|}
\hline $\begin{array}{l}\text { Authors } \\
\text { Autori }\end{array}$ & Diet supplement / Dodatak u hrani & ALA & EPA & DHA & $n-3$ PUFA \\
\hline & & \multicolumn{4}{|c|}{$\begin{array}{l}\% \text { of fatty acids in lipids of egg yolks / } \\
\% \text { masnih kiselina u lipidima žumanjka }\end{array}$} \\
\hline $\begin{array}{l}\text { Aguillon-Paez et } \\
\text { al. (2020) }\end{array}$ & $\begin{array}{l}\text { Kontrola / Control } \\
\text { Sunflower seed } 13.5 \% \text { / Suncokretovo sjeme 13,5\% } \\
\text { Linseed } 13.5 \% \text { / Laneno sjeme } 13,5 \%\end{array}$ & $\begin{array}{l}0.59 \\
0.27 \\
4.19\end{array}$ & $\begin{array}{c}- \\
- \\
0.09\end{array}$ & $\begin{array}{l}0.89 \\
0.63 \\
2.26\end{array}$ & $\begin{array}{l}1.48 \\
0.90 \\
6.54\end{array}$ \\
\hline $\begin{array}{l}\text { Petrović } \\
\text { et al. (2012) }\end{array}$ & $\begin{array}{l}\text { Control / Kontrola } \\
\text { Linseed oil 1\% / Laneno ulje 1\% } \\
\text { Linseed oil 2\% / Laneno ulje 2\% } \\
\text { Linseed oil 3\% / Laneno ulje 3\% } \\
\text { Linseed oil 4\% / Laneno ulje 4\% }\end{array}$ & $\begin{array}{l}0.50 \\
1.09 \\
1.88 \\
2.21 \\
3.22\end{array}$ & $\begin{array}{l}0.01 \\
0.01 \\
0.04 \\
0.07\end{array}$ & $\begin{array}{l}0.74 \\
1.25 \\
1.50 \\
1.55 \\
1.72\end{array}$ & $\begin{array}{l}1.24 \\
2.35 \\
3.39 \\
3.80 \\
5.01\end{array}$ \\
\hline Kralik et al. (2015) & $\begin{array}{l}\text { Control / Kontrola } \\
\text { Oil mixture 5\% / Mješavina ulja 5\% }\end{array}$ & $\begin{array}{l}0.89 \\
2.03\end{array}$ & $\begin{array}{l}0.01 \\
0.06\end{array}$ & $\begin{array}{l}0.68 \\
1.22\end{array}$ & $\begin{array}{l}1.58 \\
3.31\end{array}$ \\
\hline \multirow{2}{*}{$\begin{array}{l}\text { Kralik et al. } \\
\text { (2020c) }\end{array}$} & $\begin{array}{l}\text { Control / Kontrola } \\
\text { Linseed oil 1.5\% + fish oil 3.5\% } \\
\text { Laneno ulje 1,5\% + riblje ulje 3,5\% } \\
\text { Linseed oil 3.5\% + fish oil 1.5\% } \\
\text { Laneno ulje 3,5\% + riblje ulje 1,5\% }\end{array}$ & $\begin{array}{l}3.25 \\
5.18\end{array}$ & $\begin{array}{l}1.26 \\
0.27 \\
0.22\end{array}$ & $\begin{array}{l}1.16 \\
2.99 \\
\\
2.90\end{array}$ & $\begin{array}{l}2.42 \\
6.51 \\
8.30\end{array}$ \\
\hline & $\begin{array}{l}\text { Control / Kontrola } \\
\text { Rapeseed oil 1.5\% + fish oil 3.5\% } \\
\text { Repičino ulje 1,5\% + riblje ulje 3,5\% } \\
\text { Rapeseed oil 3.5\% + fish oil 1.5\% } \\
\text { Repičino ulje 3,5\% + riblje ulje 1,5\% }\end{array}$ & $\begin{array}{l}1.17 \\
2.31 \\
\\
1.21\end{array}$ & $\begin{array}{c}- \\
0.22 \\
0.10\end{array}$ & $\begin{array}{l}1.26 \\
2.54 \\
\\
2.23\end{array}$ & $\begin{array}{l}2.43 \\
5.07 \\
3.54\end{array}$ \\
\hline & & \multicolumn{4}{|c|}{$\begin{array}{l}\mathrm{mg} \text { fatty acids per } 100 \mathrm{~g} \text { of egg / } \\
\text { mg masnih kiselina/100 g jajeta }\end{array}$} \\
\hline $\begin{array}{l}\text { Kralik Z. } \\
\text { et al. }(2020)\end{array}$ & $\begin{array}{l}\text { Alga Schyzochytrium limacinum } 0.5 \% \\
\text { Alga Schyzochytrium limacinum } 1.0 \% \\
\text { Alga Schyzochytrium limacinum } 1.5 \% \\
\text { Fish oil } 0.5 \% \text { / Riblje ulje 0,5\% } \\
\text { Fish oil } 1.0 \% \text { / Riblje ulje 1,0\% } \\
\text { Fish oil 1.5\% / Riblje ulje 1,5\% }\end{array}$ & $\begin{array}{l}170.6 \\
199.1 \\
191.0 \\
190.6 \\
198.8 \\
207.5\end{array}$ & $\begin{array}{l}8.9 \\
4.4 \\
7.4 \\
6.3 \\
6.5 \\
9.3\end{array}$ & $\begin{array}{l}141.6 \\
142.7 \\
163.1 \\
148.9 \\
194.0 \\
152.2\end{array}$ & $\begin{array}{l}321.1 \\
346.2 \\
361.6 \\
346.2 \\
399.3 \\
369.0\end{array}$ \\
\hline $\begin{array}{l}\text { Kralik et al. } \\
\text { (2020b) }\end{array}$ & $\begin{array}{l}\text { Control / Kontrola } \\
\text { Fish oil } 0.5 \%+\text { alga Schyzochytrium I. } 0.5 \% \\
\text { Riblje ulje 0,5\% + alga Schyzochytrium I. 0,5\% } \\
\text { Fish oil } 0.75 \%+\text { alga Schyzochytrium I. } 0.75 \% \\
\text { Riblje ulje 0,75\% + alga Schyzochytrium I. 0,75\% }\end{array}$ & $\begin{array}{r}71.7 \\
177.3 \\
\\
161.0\end{array}$ & $\begin{array}{r}5.76 \\
10.4 \\
\\
7.9\end{array}$ & $\begin{array}{r}89.9 \\
152.2 \\
\\
166.5\end{array}$ & $\begin{array}{l}167.4 \\
339.9 \\
335.4\end{array}$ \\
\hline
\end{tabular}

\section{EGGS WITH INCREASED PIGMENT CONTENT IN YOLK}

The yolk color depends on the hens feeding, i.e., on the feed pigments content, primarily carotenoids. Carotenoids are divided into two large groups of molecules, xanthophylls (lutein, zeaxanthin, cryptoxanthin) containing oxygen in the molecule and carotenes ( $\alpha$-carotene, $\beta$-carotene, lycopene) being pure hydrocarbons. Xanthophylls are usually yellow in color, while the carotene color ranges from bright orange to red. If laying hens feed is supplemented with pigments whether natural or synthetic, yolk color intensity as well as yolk pigments content increase can be affected. The yolk color is one of the factors that describe eggs quality, being also very important to consumers. In most European countries consumers prefer darker color yolks confirmed by various research (Tolimir et al., 2017). Due to their fat solubility, carotenoids are deposited in the egg yolk, which thus becomes an excellent source of carotenoids in the human diet. Lutein and zeaxanthin are of a particular importance since they are the only carotenoids present in the human eye (Landrum and Bone, 2001; Gao et al., 2011). Kralik et al. (2020a) in their paper on table eggs supplemented with lutein pointed out that addition of $3 \mathrm{~g}$ of marigold flower extract $/ \mathrm{kg}$ of diet led to eggs lutein content increase from $0.72 \mathrm{mg} / 100 \mathrm{~g}$ to $7.14 \mathrm{mg} / 100 \mathrm{~g}$ of yolk. They also pointed out significantly better yolk coloration in the experimental group eggs compared to the control one $(E=13.88$ and $C=12.24 ; P<0.001)$. Grčević et al. (2019) added lutein to laying hens diet in the form of marigold flower extract ( $20 \%$ lutein). The lutein content of the yolk 
increased significantly with the lutein addition of 200 $\mathrm{mg}$ per $\mathrm{kg}$ of diet $(1 \mathrm{~g} / \mathrm{kg}$ of extract), from $20.11 \mu \mathrm{g} / \mathrm{g}$ (control group) to $107.41 \mu \mathrm{g} / \mathrm{g}$ of yolk. While added 400 $\mathrm{mg} / \mathrm{kg}$ lutein $(2 \mathrm{~g}$ marigold flower extract), the lutein content in the yolk increased further to $118.86 \mu \mathrm{g} / \mathrm{g}$. After color analysis of the fresh egg yolks and those stored for 28 days in a refrigerator $\left(4^{\circ} \mathrm{C}\right)$, the authors found out a significant increase in the yolk color value in experimental groups in relation to control group. The value of fresh egg yolk color increased from 12.90 in control group to 13.67 and 13.77 in groups with addition of 200 and $400 \mathrm{mg} / \mathrm{kg}$ lutein, respectively. Yolk color values for eggs stored in refrigerator were 13.10 in the control group, while in experimental groups values were 14.13 and 14.40 , respectively. During egg storage, water loss and gas exchange between the environment and the egg occurs. These changes lead to the dilution of the egg albumen while the yolk is concentrated, and thus the pigments in it. We hypothesize that the higher yolk color values in stored eggs in the study of Grčević et al. (2019) are due to the changes mentioned above. The results of Giampietro-Ganeco et al. (2012) agree with our assumption. In the study of Englmaierová and Skrivan (2013), while adding $100 \mathrm{mg} / \mathrm{kg}$ of lutein into the laying hens feed, the lutein content in egg yolks increased from 16.09 to $31.68 \mathrm{mg} / \mathrm{kg}$ of egg yolk dry matter $(\mathrm{P}<0.001)$ whereas the yolk color increased from 7.7 in the control group to 8.4 in the experimental group. When laying hens feed was supplemented with $250 \mathrm{mg} / \mathrm{kg}$ of lutein the yolk lutein content was 133.90 $\mathrm{mg} / \mathrm{kg}$ of yolk dry matter $(\mathrm{P}<0.001)$ compared to 12.80 $\mathrm{mg} / \mathrm{kg}$ in the lutein-free group (Englmaierová et al., 2013). Based upon the study of these authors, the color of the yolk was significantly higher $(P<0.001)$ in the experimental (13.1) compared to the control (6.4) group. Skřivan et al. (2016) also added marigold flower extract containing $21.26 \mathrm{mg} / \mathrm{kg}$ lutein into the laying hens feed at concentrations of $150,350,550,750$, and $950 \mathrm{mg} / \mathrm{kg}$ of diet. The highest yolk lutein content was recorded in the group with the highest addition of marigold extract into laying hens feed being $36.33 \mathrm{mg} / \mathrm{kg}$ of egg yolk dry matter whereas in the control group the yolk lutein content was $12.34 \mathrm{mg} / \mathrm{kg}$ of dry matter. The yolk value color significantly $(\mathrm{P}<0.001)$ increased even while adding $150 \mathrm{mg} / \mathrm{kg}$ of marigold extract (from 5.67 to 7.31 ) while the highest color value of (10.55) was recorded in the group with the addition of $950 \mathrm{mg} / \mathrm{kg}$ of marigold extract. The yolk color values in the above studies were measured using a DSM ${ }^{\circledR}$ Yolk Color Fan (YCF) having a scale of 1-15. Skrivanova et al. (2017) found out that carotenoids (lutein and zeaxanthin) are better retained in egg yolks when marigold extract is added into the laying hens feed than when Chlorella algae or pure lutein was used as supplements. All the above-mentioned studies confirm the possibility of carotenoid content increase in egg yolks by adding different carotenoids sources into the laying hens feed, whereby the eggs produced in this way become an excellent source of carotenoids, primarily lutein and zeaxanthin in human diet.

\section{HEALTH BENEFITS OF DESIGNER EGGS CONSUMPTION}

Eggs are an excellent source of protein, fat, vitamins, and minerals. They are considered a global functional product representing a "complete" food required for the growth and metabolic processes regulation (Singh et al., 2012; Zaheer, 2015). Egg protein quality is high being the standard for evaluating other foods (Sparks, 2006). Eggs contain fat-soluble vitamins: A, D, $E$ and $K$, as well as water-soluble ones: thiamine (B1), riboflavin (B2), pantothenic acid (B5), pyridoxine (B6), biotin (B7), folic acid (B9), cobalamin (B12) and choline. They also contain minerals: calcium, iron, magnesium, phosphorus, selenium, sodium, and zinc (Zaheer, 2015). Shakoor et al. (2020) found out that n-3 PUFA eggs consumption has a positive effect on decreasing cholesterol, triglycerides, LDL cholesterol, blood pressure, and promotes HDL cholesterol concentration increase. Thus, eggs supplemented with n-3 PUFA may be useful in maintaining normal heart function. Technological procedures of egg yolks cholesterol concentration reduction are also significant (Khan et al., 2017; Sireesha and Prasanna, 2019). Hu et al. (1999) found out that cholesterol rich eggs could increase total food intake by $32 \%$. Weggemans et al. (2001) found out that 100 $\mathrm{mg}$ of egg cholesterol raised total plasma cholesterol by $0.057 \mathrm{mmol} / \mathrm{L}$ in clinical trials. Kuang et al. (2018) stated that cholesterol homeostasis is affected by food intake, endogenous biosynthesis, utilization, and excretion. Stupin et al. (2018) investigated the effect of n-3 PUFAenriched egg consumption on endothelium-dependent and endothelium-independent vasodilation in the microcirculation and endothelial activation and inflammation in young, healthy persons. They concluded that the n-3 PUFA consumption improved microvascular endothelium-dependent vasodilation in healthy persons due to their anti-inflammatory potential. Polyunsaturated fatty acids ALA (n-3) and linoleic acid-LA (n-6) are essential for human health (Zaheer, 2015). LA is metabolized to arachidonic acid whereas ALA to EPA and DHA. These essential long-chain fatty acids are components of phospholipids contributing to the cell membranes flexibility and plasma cholesterol reduction. EPA and DHA also reduce cardiovascular and central nervous system diseases, mental illness, inflammation, and immune infections risk (Fraeye et al., 2012). Nutritionists recommend n-3 PUFA consumption increase. According to the EANS (European Academy of Nutritional Sciences), the EPA + DHA daily consumption should be $0.2 \mathrm{~g}$ (Ruxton et al., 2004). However, the FAO-WHO, the socalled AMDR (Acceptable Macronutrient Distribution Range), recommends daily consumption of ALA + EPA + DHA 0.25-2.0 g (Bubel et al., 2011), and Elmadfa and Kornsteiner (2009) stated an upper limit of $3.0 \mathrm{~g} /$ day for EPA and DHA since higher concentrations reduce cytokine production and increase lipid peroxidation. Some countries, such as France, recommend $500 \mathrm{mg} /$ day, or Norway, 1-2 g daily consumption of EPA + 
DHA. The International Society for the Study of Fatty Acids and Lipids (ISSFAL) also recommends $500 \mathrm{mg} /$ day whereas NATO considers adult needs for EPA + DHA to be $800 \mathrm{mg} /$ day (Candela et al., 2011). Egg yolk contains various carotenoids affecting the yolk color and having a protective effect on the occurrence of cataracts and macular degeneration associated with aging (Ribaya-Mercado and Blumberg, 2004). They also increased antioxidant capacity and reduced peroxidative lipid damage (Cucco et al., 2007). Eggs enriched with carotenoids, primarily lutein and zeaxanthin, are an excellent source of these ingredients in the human diet. It has been proved that the bioavailability of yolk lutein is higher compared to plant sources whereby cholesterol content and fatty acid composition in yolks affected better utilization and increased lutein content in human serum (Chung et al., 2004). Lutein plays the roles of both an antioxidant and a filter of harmful blue light in the eyes. In this way it prevents damage of photoreceptors in the eye being important for maintaining good central vision and visual acuity (Nilsson et al., 2003). Due to the blue light filtering properties, the role of lutein in maintaining skin health is also being investigated. Palombo et al. (2007) showed that the lutein $(5 \mathrm{mg})$ intake for 12 weeks has reduced skin lipid peroxidation and increased hydration, lipid content and skin elasticity. The study by Johnson et al. (2013) shows that lutein with $34 \%$ is the most represented carotenoid in the adult brain, whereas Vishwanathan et al. (2014) found out that this share is even higher in the brain of children amounting $59 \%$. Thus, lutein effect on the nervous system development in children as well as on the preservation of cognitive functions in the elderly is being investigated. Perrone et al. (2010) found out that lutein in neonatal serum significantly increased antioxidant activity. Results of the Johnson et al. (2008) study showed a significant speech fluency improvement in women aged 60-80 years, who consumed lutein supplements (12 mg per day), docosahexaenoic acid (DHA, $800 \mathrm{mg}$ per day), or their combinations for 4 months. It was also determined that memory and learning speed as well as the more effective learning trend significantly improved in subjects (women) in the group with lutein and DHA combination.

\section{CONCLUSION}

Designer eggs concept aims to enrich eggs with one or more nutrients, increase egg consumption per capita and provide a new product on the functional food market. The term "functional food", first recorded in Japan in the 80's, was used for food products that have been modified with one or more nutrients in order to prevent human health. Today, on the world market, there are eggs enriched with various nutrients whose consumption has a preventive effect on human health. Eggs enriched with omega- 3 fatty acids are available on the market in the Republic of Croatia, and their consumption has been proved to have a positive effect on cardiovascular function in humans. From a technological point of view, enrichment of eggs with nutrients usually involves higher production costs and their price is somewhat higher compared to conventionally produced ones. Thus, the health benefits of consuming designer eggs should be pointed out using appropriate packaging labels.

\section{ACKNOWLEDGEMENTS}

This study is supported by the European Structural and Investment Fund's grant for the Croatian National Scientific Center of Excellence for Personalized Health Care (grant \#KK.01.1.1.01.0010) and by the Ministry of Science and Education of the Republic of Croatia.

\section{REFERENCES}

1. Aguillon-Paez, Y. J., Romero, L. A., \& Diaz, G. J. (2020). Effect of full-fat sunflower or flaxseed seeds dietary inclusion on performance, egg yolk fatty acid profile and egg quality in laying hens. Animal Nutrition, 6(2), 179184. https://doi.org/10.1016/j.aninu.2019.12.005

2. Alves-Rodrigues, A., Shao, A. (2004): The science behind lutein. Toxicology Letters, 150(1), 57-83.

3. Aydin, R., \& Dogan, I. (2010). Fatty acid profile and cholesterol content of egg yolk from chickens fed feed supplemented with purslane (Portulaca oleracea L.). Journal of the Science of Food and Agriculture, 90(10), 1759-1763. https://doi.org/10.1002/jsfa.4018

4. Basmacıoğlu, H., Çabuk, M., Ünal, K., Özkan, K., Akkan, S., \& Yalçın, H. (2003). Effects of dietary fish oil and flax seed on cholesterol and fatty acid composition of egg yolk and blood parameters of laying hens. South African Journal of Animal Science, 33(4), 266-273.

5. Baucells, M. D., Crespo, N., Barroeta, A. C., Lopez-Ferrer, S., \& Grashorn, A. M. (2000). Incorporation of different polyunsaturated fatty acids into eggs. Poultry Science, 79(1), 51-59. https://doi.org/10.1093/ps/79.1.51

6. Bech-Larsen, T., \& Grunert, K. G. (2003). The perceived healthiness of functional foods $A$ conjoint study of Danish, Finnish and American consumers' perception of functional foods. Appetite, 40(1): 9-14. https://doi.org.10.1016/S0195-6663(02)00171-X

7. Biacs, P. A. (2007). Regulations and claims of functional foods. In Proceedings of the fourth international FFNet meeting on functional foods.

8. Bubel, F., Dobrzański, Z., Bykowski, P., PatkowskaSokoła, B., \& Trziszka, T. (2011). Enrichment of hen eggs with omega-3 polyunsaturated fatty acids - physiological and nutritional aspects. Acta Scientiarum PolonorumMedicina Veterinaria, 10(3), 5-18.

9. Candela, C. G., López, L. B., \& Kohen, V. L. (2011). Importance of a balanced omega 6/omega 3 ratio for the maintenance of health. Nutritional recommendations. Nutricion hospitalaria, 26(2), 323-329. https://doi.org/10.1590/S0212-16112011000200013

10. Chung, H. Y., Rasmussen, H. M., \& Johnson, E. J. (2004). Lutein bioavailability is higher from lutein-enriched eggs 
than from supplements and spinach in men. The Journal of Nutrition, 134(8), 1887-1893.

http://doi.org/10.1093/jn/134.8.1887

11. Coorey, R., Novinda, A., Williams, H., \& Jayasena, V. (2015). Omega-3 fatty acid profile of eggs from laying hens fed feed supplemented with chia, fish oil, and flaxseed. Journal of Food Science, 80(1), 180-187. https://doi.org/10.1111/1750-3841.12735

12. Cucco, M., Guasco, B., Malacarne, G., Ottonelli, R. (2007). Effects of $\beta$-carotene on adult immune condition and antibacterial activity in the eggs of the Grey Partridge, Perdix perdix. Comparative Biochemistry and Physiology, Part A: Molecular \& Integrative Physiology. 147(4): 1038-1046. https://doi.org/10.1016/j.cbpa.2007.03.014

13. Djoussé, L., \& Gaziano, J. M. (2008). Egg consumption in relation to cardiovascular disease and mortality: the Physicians' Health Study. The American Journal of Clinical Nutrition, 87(4), 964-969. https://doi.org/10.1093/ajcn/87.4.964

14. Eilat-Adar, S., Sinai, T., Yosefy, C. \& Henkin, Y. (2013). Nutritional recommendations for cardiovascular disease prevention. Nutrients, 5(9), 3646-3683. http://doi.org/10.3390/nu5093646

15. Elmadfa, I., \& Kornsteiner, M. (2009). Fats and fatty acid requirements for adults. Annals of Nutrition \& Metabolism, 55(1/3), 56-75. https://doi.org10.1159/000228996

16. Englmaierová, M., \& Skřivan, M. (2013). Effect of synthetic carotenoids, lutein, and mustard on the performance and egg quality. Scientia agriculturae bohemica, 44(3), 138-143. https://doi.org/10.7160/sab.2013.440303

17. Englmaierová, M., Skřivan, M., \& Bubancova, I. (2013). A comparison of lutein and spray-dried Chlorella, and synthetic carotenoids effects on yolk colour, oxidative stability, and reproductive performance of laying hens. Czech Journal of Animal Science, 58(9), 412-419. https://doi.org/10.17221/6941-CJAS

18. Fraeye, I., Bruneel, C., Lemahieu, C., Butse, J., Muylaert, K., \& Foubert, I. (2012). Dietary enrichment of eggs with omega-3 fatty acids: a review. Food Research International, 48(2), 961-969. http:// doi.org/10.1016/j.foodres.2012.03.014

19. Gao, S., Qin, T., Liu, Z., Caceres, M. A., Ronchi, C. F., Chen, C. Y., Yeum, K. J., Taylor, A., Blumberg, J. B., Liu, Y., \& Shang, F. (2011). Lutein and zeaxanthin supplementation reduces $\mathrm{H} 2 \mathrm{O} 2$-induced oxidative damage in human lens epithelial cells. Molecular Vision, 17, 31803190.

20. Giampietro-Ganeco, A., Scatolini-Silva, A. M., Borba, H., Boiago, M. M., Lima, T. M. A., \& Souza, P.A. (2012). Comparative study of quality characteristics of egg stored in domestic refrigerators. Ars Veterinaria, 28(2), 100-104.

http://dx.doi.org/10.15361/2175-0106.2012v28n2p100-104

21. Grčević, M., Kralik, Z., Kralik, G., \& Galović, O. (2019). Effects of dietary marigold extract on lutein content, yolk color and fatty acid profile of omega-3 eggs. Journal of the Science of Food and Agriculture, 99(5), 2292-2299. https://doi.org/10.1002/jsfa.9425

22. Hu, F. B., Stampfer, M. J., Rimm, E. B., Manson, J. E., Ascherio, A., Colditz, G. A., \& Hennekens, C. H. (1999). A prospective study of egg consumption and risk of cardiovascular disease in men and women. JAMA, 281(15), 1387-1394. https://doi.org/10.1001/jama.281.15.1387

23. Johnson, E. J., McDonald, K., Caldarella, S. M., Chung, H. Y., Troen, A. M., \& Snodderly, D. M. (2008). Cognitive findings of an exploratory trial of docosahexaenoic acid and lutein supplementation in older women. Nutritional Neuroscience, 11(2), 75-83. https://doi.org/10.1179/147683008X301450

24. Johnson, E. J., Vishwanathan, R., Johnson, M. A. Hausman, D. B., Davey, A., Scott, T. M., ... \& Poon, L. W. (2013). Relationship between serum and brain carotenoids-tocopherol, and retinol concentrations and cognitive performance in the oldest old from the Georgia Centenarian Study. Journal of Aging Research, Article ID 951786, 13 pages. http://doi.org/10.1155/2013/951786

25. Khan, S. A., Khan, A., Khan, S. A., Beg, M. A., Ali, A., \& Damanhouri, G. (2017). Comparative study of fatty-acid composition of table eggs from the Jeddah food market and effect of value addition in omega- 3 bio-fortified eggs. Saudi Journal of Biological Sciences, 24(4), 929935. https://doi.org/10.1016/j.sjbs.2015.11.001

26. Kralik, I, Kralik, Z., \& Grčević, M. (2016). 0 čemu ovisi kupovina funkcionalnih prehrambenih proizvoda? Krmiva, 57(1), 29-36.

27. Kralik, G., Kralik, Z., Grčević, M., Kralik, I., \& Hanžek, D. (2015). The effect of feeding laying hen conventional and omega-3 enriched diet on fatty acid profiles in egg yolk lipids. Journal of Agricultural Science and Technology B, 5, 506-511. https://doi.org/10.17265/2161-6264/2015.07.009

28. Kralik, Z., Kralik, G., Grčević, M., Kralik, I., \& Gantner, V. (2018). Physical-Chemical characteristics of designer and conventional eggs. Brazilian Journal of Poultry Science, 20(1), 119-126. https://doi.org/10.1590/1806-9061-2017-0631

29. Kralik, Z., Kralik, G., Grčević, M., Hanžek, D., \& Margeta, P. (2020). Microalgae Schizochytrium limacinum as an alternative to fish oil in enriching table eggs with n-3 polyunsaturated fatty acids. Journal of the Science of Food and Agriculture, 100(2), 587-594.

https://doi.org/10.1002/jsfa.10052

30. Kralik, G., Kralik, Z., Grčević, M., Hanžek, D., Margeta, P., \& Galović, 0. (2020a). Enrichment of table eggs with lutein. Poljoprivreda, 26(1): 56-63. http://dx.doi.org/10.18047/poljo.26.1.8

31. Kralik, G., Grčević, M., Hanžek, D., Margeta, P., Galović, 0., \& Kralik, Z. (2020b). Feeding to produce n-3 fatty acid-enriched table eggs. The Journal of Poultry Science, 57(2), 138-147. https://doi.org/10.2141/jpsa.0190076

32. Kralik, G., Kralik, Z., \& Hanžek, D. (2020c). The effect of vegetable oils and the fish oil on the fatty acid profile in egg yolks. Poljoprivreda, 26(2), 79-87. https://doi.org/10.18047/poljo.26.2.10

33. Kuang, H., Yang, F., Zhang, Y., Wang, T., \& Chen, G. (2018). The impact of egg nutrient composition and its consumption on cholesterol homeostasis. Cholesterol, Article ID 6303810, 22 pages. https://doi.org/10.1155/2018/6303810

34. Labrecque, J., Doyon, M., Bellavance, F., \& Kolodinsky, J. (2006). Acceptance of functional foods: A comparison 
of French, American, and French Canadian consumers. Canadian Journal of Agricultural Economics/Revue canadienne d'agroeconomie, 54(4), 647-661.

35. Landrum, J., \& Bone, R. (2001): Lutein, zeaxanthin, and the macular pigment. Archives of Biochemistry and Biophysics, 385(1), 28-40. https://doi.org/10.1006/abbi.2000.2171

36. Lesnierowski, G., \& Stangierski, J. (2018). What's new in chicken egg research and technology for human health promotion? - A review. Trends in Food Science \& Technology, 71, 46-51. https://doi.org/10.1016/j.tifs.2017.10.022

37. Lešić, T., Vulić, A., Cvetnić, L., Kudumija, N., Škrivanko, M., \& Pleadin, J. (2015). Udio masti i sastav masnih kiselina u kokošjim jajima hrvatskih proizvođača. Veterinarska stanica: znanstveno-stručni veterinarski časopis, 46(5), 349-358.

38. Li, Y., Zhou, C., Zhou, X., \& Li, L. (2013). Egg consumption and risk of cardiovascular diseases and diabetes: a meta-analysis. Atherosclerosis, 229(2): 524-530.

39. Lusk, J. L., House, L. O., Valli, C., Jaeger, S. R., Moore, M., Morrow, J. L., \& Traill, W. B. (2004). Effect of information about benefits of biotechnology on consumer acceptance of genetically modified food: evidence from experimental auctions in the United States, England, and France. European Review of Agricultural Economics, 31(2), 179-204. https://doi.org/10.1093/erae/31.2.179

40. Lusk, J. L., \& Rozan, A. (2005). Consumer acceptance of biotechnology and the role of second-generation technologies in the USA and Europe. Trends in Biotechnology, 23(8), 386-387.

https://doi.org/10.1016/j.tibtech.2005.05.012

41. Lyons, M. P., Papazyan, T. T., \& Surai, P. F. (2007). Selenium in food chain and animal nutrition: lessons from nature-review. Asian-Australasian Journal of Animal Sciences, 20(7), 1135-1155. https://doi.org/10.5713/ajas.2007.1135

42. Mattioli, S., Dal Bosco, A., Martino, M., Ruggeri, S., Marconi, 0., Sileoni, V., ... \& Benincasa, P. (2016). Alfalfa and flax sprouts supplementation enriches the content of bioactive compounds and lowers the cholesterol in hen egg. Journal of Functional Foods, 22, 454-462. https://doi.org/ 10.1016/j.jff.2016.02.007

43. Muduli, S., Champati, A., \& Popalghat, H. K. (2018). Designer egg: a new approach in modern health care. The Pharma Innovation, 7(5), 320-326.

44. Nilsson, S. E. G., Sundelin, S. P., Wihlmark, U., \& Brunk, U. T. (2003). Aging of cultured retinal pigment epithelial cells: oxidative reactions, lipofuscin formation and blue light damage. Documenta Ophthalmologica, 106(1), 13-16. https://doi.org/10.1023/a:1022419606629

45. Palombo, P., Fabrizi, G., Ruocco, V., Ruocco, E., Fluhr, J., Roberts, R., \& Morganti, P. (2007). Beneficial long-term effects of combined oral/topical antioxidant treatment with the carotenoids lutein and zeaxanthin on human skin: a double-blind, placebo-controlled study. Skin pharmacology and physiology, 20(4), 199-210. https://doi.org/10.1159/000101807

46. Perrone, S., Longini, M., Marzocchi, B., Picardi, A., Bellieni, C. V., Proietti, F., ... \& Buonocore, G. (2010).
Effects of lutein on oxidative stress in the term newborn: a pilot study. Neonatology, 97(1), 36-40. https://doi.org/10.1159/000227291

47. Petrović, M., Gačić, M., Karačić, V., Gottstein, Ž., Mazija, H., \& Medić, H. (2012). Enrichment of eggs in n-3 polyunsaturated fatty acids by feeding hens with different amount of linseed oil in diet. Food Chemistry, 135(3), 1563-1568. https://doi.org/10.1016/j.foodchem.2012.06.020

48. Ribaya-Mercado, J. D., Blumberg, J. B. (2004): Lutein and zeanthin and their potential roles in disease prevention. Journal of the American College Nutrition, 23(6), 567-587. https://doi.org/10.1080/07315724.2004.10719427.

49. Ruxton, C. H. S., Reed, S. C., Simpson, M. J. A., \& Millington, K. J. (2004). The health benefits of omega-3 polyunsaturated fatty acids: a review of the evidence. Journal of Human Nutrition and Dietetics, 17(5), 449459. https://doi.org/10.1111/j.1365-277X.2004.00552.x

50. Sahoo, A., \& Jena, B. (2014). Designer egg and meat through nutrient manipulation. Journal of Poultry Science and Technology, 2(3), 38-47.

51. Shakoor, H., Khan, M. I., Sahar, A., Khan, M. K. I., Faiz, F., \& Basheer Ahmad, H. (2020). Development of omega-3 rich eggs through dietary flaxseed and bio-evaluation in metabolic syndrome. Food Science \& Nutrition, 8(6), 2619-2626. https://doi.org/10.1002/fsn3.1522

52. Simopoulos, A. P. (2000). Symposium: Role of poultry products in enriching the human diet with n-3 PUFA. Poultry Science, 79(7), 961-970. https://doi.org/10.1093/ps/79.7.961

53. Singh, V. P., Pathak, V. \& Akhilesh, K. V. (2012). Modified or enriched eggs: a smart approach in egg industry: a review. American Journal of Food Technology, 7(5), 266277. http://dx.doi.org/10.3923/ajft.2012.266.277

54. Sireesha, P., \& Prasanna, S. (2019). Designer eggs and poultry meat as functional foods - an overview. Journal of Pharmaceutical Innovation, 8(4), 829-831.

55. Skřivan, M., Marounek, M., Englmaierová, M., \& Skřivanová, E. (2016). Effect of increasing doses of marigold (Tagetes erecta) flower extract on eggs carotenoids content, colour and oxidative stability. Journal of Animal and Feed Sciences, 25(1), 58-64. https://doi.org/10.22358/jafs/65588/2016

56. Skřivanova, V., Englmaierova, M., Bendova, M., \& Skrivan, M. (2017): The effect of the source and level of carotenoids in feed on their retention in eggs. Czech Journal of Animal Science, 62(8), 323-330. https://doi.org/10.17221/17/2017-CJAS

57. Sparks, N. H. C. (2006). The hen's egg-is its role in human nutrition changing? World's Poultry Science Journal, 62(2), 308-315. https://doi.org/10.1079/WPS200599

58. Stibilj, V., Koman Rajšp, M., \& Holcman, A. (1999). Fatty acid composition of eggs enriched with omega-3 fatty acids on the market. Zbornik Biotehniške fakultete Univerze v Ljubljani, Kmetijstvo, Zootehnika, 74(2), 27-36.

59. Stupin, A., Rasic, L., Matic, A., Stupin, M., Kralik, Z., Kralik, G., ... \& Drenjancevic, I. (2018). Omega-3 polyunsaturated fatty acids-enriched hen eggs consumption 
enhances microvascular reactivity in young healthy individuals. Applied Physiology, Nutrition, and Metabolism, 43(10), 988-995.

https://doi.org/10.1139/apnm-2017-0735

60. Surai, P. F., \& Sparks, N. H. C. (2001). Designer eggs: from improvement of egg composition to functional food. Trends in Food Science \& Technology, 12(1), 7-16. https://doi.org/10.1016/S0924-2244(01)00048-6

61. Tolimir, N., Maslovarić, M., Škrbić, Z., Lukić, M., Rajković, B., \& Radišić, R. (2017). Consumer criteria for purchasing eggs and the quality of eggs in the markets of the city of Belgrade. Biotechnology in Animal Husbandry, 33(4), 425-437. https://doi.org/10.2298/BAH1704425T

62. Vishwanathan, R., Kuchan, M. J., Sen, S., Johnson, E. J. (2014). Lutein and preterm infants with decreased concentrations of brain carotenoids. Journal of Pediatric Gastroenterology and Nutrition, 59(5), 659-665. https://doi.org/10.1097/MPG.0000000000000389
63. Weggemans, R. M., Zock, P. L., \& Katan, M. B. (2001) Dietary cholesterol from eggs increases the ratio of total cholesterol to high-density lipoprotein cholesterol in humans: a meta-analysis. American Journal of Clinical Nutrition, 73(5), 885-891. https://doi.org/10.1093/ajcn/73.5.885

64. Williams, P. G., Ridges, L., Batterham, L., Ripper, B., \& Hung, M. C. (2008). Australian consumer attitudes to health claim - food product compatibility for functional foods. Food Policy, 33(6), 640-643. https://doi.org/10.1016/j.foodpol.2008.06.001

65. Zaheer, K. (2015). An updated review on chicken eggs: production, consumption, management aspects and nutritional benefits to human health. Food and Nutrition Sciences, 6(13), 1208-1220. https://doi.org/10.4236/fns.2015.613127

\section{DIZAJNIRANA JAJA S POVEĆANIM SADRŽAJEM OMEGA-3 MASNIH KISELINA I PIGMENATA — PROIZVODNJA I ZDRAVSTVENA KORIST NJIHOVE KONZUMACIJE}

\section{SAŽETAK}

Proteklih godina u animalnoj proizvodnji i prehrambenoj industriji dizajnirani-obogaćeni proizvodi predstavljaju jedno od najzanimljivijih područja istraživanja i inovacija. Ovi proizvodi smatraju se funkcionalnom hranom $i$ sadrže sastojke koji imaju povoljne fiziološke učinke na ljudsko zdravlje. U peradarskoj proizvodnji dizajnirana ili obogaćena jaja važna su vrsta funkcionalne hrane. Potražnja funkcionalne hrane na tržǐšu zadnjih godina je u porastu. Upravo zbog povećanoga interesa ljudi za kupovinom dizajniranih proizvoda dolazi do prilagodbe proizvodnje u peradarskoj industriji. Izmjenom sastava krmnih smjesa za nesilice utječe se na promjenu nutritivnoga sastava jaja, kao i na očuvanje njihove kvalitete. Ovim postupkom u jajima se može postići promjena koncentracije kolesterola i njegovih frakcija, masnih kiselina i pigmenata. Iz relevantne znanstvene literature uočljivo je da se konzumacijom dizajniranih jaja može pozitivno utjecati na zdravstveno stanje ljudi. Stoga je i cilj rada opisati različite koncepte proizvodnje dizajniranih jaja te istaknuti zdravstvenu dobrobiti njihove konzumacije kod ljudi.

Ključne riječi: dizajnirana jaja, funkcionalna hrana, omega-3 masne kiseline, pigmenti

(Received on April 12, 2021; accepted on June 8, 2021 - Primljeno 12. travnja 2021.; prihvaćeno 8. lipnja 2021.) 